\title{
Iniciação, Profanação e Mitopeia no Banquete de Platão: uma aproximação entre literatura e filosofia
}

\section{Adriano Scandolara*}

Resumo: O presente artigo pretende fazer uma breve análise da estrutura e das ideias presentes no diálogo $O$ Banquete, de Platão, levando em conta não só o seu aspecto de texto filosófico, mas também sua elaboração altamente literária. Desse modo, exploramos a possibilidade de se ver o texto como uma obra icônica, em que a forma de apresentação reflete o conteúdo, na medida em que seu aspecto narrativo não se limita a ser um veículo para exposição de ideias. Para tanto, recorremos à abordagem da crítica literária, além de referências a outras obras e textos de comentadores, começando com a análise da estrutura geral do diálogo, tendo em vista sua semelhança às práticas dos mistérios de Elêusis e, a partir daí, apontando para a questão do mito e como ele é visto e trabalhado na esfera da religião, em contraposição com a esfera de uma tradição narrativa e filosófica.

Palavras-chave: diálogo platônico, mito, mistérios de Elêusis.

Abstract: The present article aims to analyze briefly the structure and ideas present in Plato's dialogue, The Symposium, taking into consideration not only its aspect as a philosophical text, but also its highly literary elaboration. In this manner, we explored the possibility of regarding the text as an iconic piece, in which the form of presentation reflects its content, as its narrative aspects aren't limited to being a vehicle for the exposition of ideas. To do so, we've recurred to the approach of literary criticism, as well as references to other works and texts by commentators, starting with the analysis of the dialogue's general structure, having in mind its

* Bacharel em Letras e mestrando em Estudos Literários pela Universidade Federal do Paraná. Contato: adrianoscandolara@gmail.com 
resemblance to the practices of Eleusis' mysteries and, from then on, pointing out to the matter of the myth and how it is perceived and worked upon in the religious sphere, as opposed to the sphere of a narrative and philosophical tradition.

Keywords: platonic dialogue, myth, Eleusis' mysteries.

\section{O Banquete e os Mistérios de Elêusis}

É desnecessário afirmar que $O$ Banquete, de Platão é um importante texto filosófico. No entanto, ao contrário do que se tornou a norma dos textos filosóficos no Ocidente, seu formato é narrativo, em vez de expositivo, e ele nos apresenta o comportamento de seus personagens como se numa peça de teatro ou num romance, narrando um banquete à noite na casa do jovem poeta Ágathon comemorando sua vitória num concurso dramático recente. Nele estiveram presentes como convidados Fedro, Pausânias, Erixímaco, Aristófanes e, mais tardiamente, Alcebíades, além do filósofo Sócrates, todos eles figuras históricas, e o que os envolve, nessa noite, é uma discussão sobre a natureza do amor - mais especificamente, o amor do tipo eros, sexual, em oposição a agape ou philia, no grego. Várias já foram as interpretações sobre o diálogo: ele já foi lido pensando em Platão como valendo-se do personagem de Sócrates como um veículo para transmitir suas próprias ideias, como também já foi visto, por uma tradição de leitura cética, como uma refutação de qualquer verdade filosófica. Atualmente, existe também uma 
chamada terceira via de leitura ${ }^{1}$, que busca considerar tanto as ideias quanto as estruturas presentes nos diálogos para interpretá-los. É evidente que, em oposição aos textos filosóficos de natureza mais expositiva, esse aspecto mimético-narrativo do diálogo relativiza e compromete o que poderia ser uma compreensão clara dos conceitos atribuíveis a Platão.

Iniciamos nossa discussão repetindo a constatação que outros comentadores $^{2}{ }^{3}$ já fizeram: a de que o banquete propriamente dito que ocorre no diálogo homônimo de Platão é construído com base numa tradição antiga que é a da iniciação em ritos de mistério, mais especificamente nesse caso, os mistérios de Elêusis. Os mistérios de Elêusis eram ritos religiosos em honra à deusa da fertilidade Deméter e sua filha Prosérpina, de caráter algo desviante dos ritos típicos de sacrifício animal da sociedade grega. Eles ocorriam uma vez por ano na região de Elêusis, a alguns quilômetros de Atenas, e persistiram por pelo menos mil anos, até a destruição de seu santuário pelos godos ${ }^{4}$. Um de seus elementos mais distintos é o fato de ser um culto primariamente dedicado ao feminino e sem o intermédio de sacerdotes masculinos. Elencarei, aqui, resumidamente, alguns

${ }^{1}$ GONZÁLEZ, Francisco J. The Third Way: new directions in platonic studies. London: Rowman \& Littlefiled, 1995.

${ }^{2}$ EVANS, Nancy. Diotima and Demeter as Mystagogues in the Symposium. In: Hypatia, vol. 21, no. 2. 2006.

${ }^{3}$ LOREDO, Carlos Roberto. Eros e Iniciação: Um estudo sobre as relações entre a paidéia platônica e os antigos cultos gregos de Mistério a partir do Banquete. Dissertação de Mestrado. Belo Horizonte: FAJE, 2009.

${ }^{4}$ LOREDO. Ibid., p. 21. 
elementos que permitam a comparação entre tais rituais e a estrutura do Banquete.

Primeiramente, temos o fato de que os ritos de Elêusis eram um culto paralelo ao culto tradicional da sociedade grega, no sentido de que não envolvia o sacrifício animal mediado por sacerdotes. Tal mediação era perpetuadora de uma relação de controle e de hierarquização, tanto de classe social - pois os sacerdotes e magistrados oficiais, responsáveis pela organização do evento, faziam parte da aristocracia ${ }^{5}$ - quanto de sexo/gênero - pois tais atividades eram naturalmente masculinas. Enquanto isso, os cultos de mistério eram públicos e comunais, onde os próprios participantes assumiam as funções de mediação com o divino pessoalmente ${ }^{6}$. Eram admitidos até mesmo não cidadãos, como mulheres, escravos e estrangeiros, com exceção apenas dos "bárbaros" (que não compreendiam a língua) e assassinos ${ }^{7}$. Essa relação de igualdade é vista no Banquete na maneira como o discurso que é reconhecidamente o grande discurso da noite é dado por alguém cuja classe social não é a mais alta (na verdade, Alcebíades, tendo a posição hierárquica mais alta, é quem fala de modo mais constrangedor) e sua fala é a repetição da fala de uma outra pessoa, que é não só uma mulher, como uma sacerdotisa e estrangeira. E isso tem a ver com o segundo elemento que é a presença do feminino, uma noção fundamental para os Mistérios, que celebram uma relação estritamente feminina entre mãe

\footnotetext{
${ }^{5}$ LOREDO. Idem. p. 22.

${ }^{6}$ EVANS. Ibid., p. 3.

${ }^{7}$ LOREDO. Ibid., p. 22.
} 
(Deméter) e filha (Prosérpina). É, contudo, um fato que até a fala de Sócrates, o ambiente no Banquete é predominantemente masculino (todos os convivas são homens e mesmo as flautistas são expulsas no começo) e ateniense, assim como é predominantemente aristocrático e de educação sofista.

Mas há ainda outros elementos relevantes. Segundo Loredo ${ }^{8}$, "ao falar sobre o amor e a sua força educativa escolhendo como moldura para esta fala um banquete, Platão cria uma primeira condição, a condição geral da ambiência ou contexto da narração, para relacionar o amor educativo aos ritos e símbolos das iniciações", visto que "os banquetes eram cenas típicas do ambiente dos Mistérios". E, a partir daí, a presença de todo vocabulário relacionado ao ritual permeia a obra inteira, presente principalmente no discurso de Aristófanes e de Alcebíades ${ }^{9}$ e de Sócrates $^{10}$. Ambos os comentadores identificam termos como mystes, symbolon, teletai, tas teletas, muetheies, erotika, telea, epoptika, tiktein e theophiles como pertencentes a esse campo semântico, além de outros recursos discursivos sobre os quais não me estenderei aqui.

Deméter era reconhecida como deusa da fertilidade e vemos como a fertilidade, do corpo e da alma, faz parte do discurso de Sócrates/Diotima. Ela foi a deusa que, segundo a mitologia, ensinou os humanos em Elêusis a semear suas plantações e, desse modo, o seu culto de mistério remete à celebração desse aprendizado. Assim

\footnotetext{
${ }^{8}$ LOREDO. Idem., p. 88.

${ }^{9}$ LOREDO. Ibid., pp. 89-91.

${ }^{10}$ EVANS. Ibid., pp. 16-19.
} 
também, Sócrates tendo aprendido de Diotima a semear a sabedoria, por assim dizer (e é-nos muito apropriada a imagem da semente como sendo o estado inicial de algo que busca um estágio de totalidade), repassa o seu conhecimento aos outros convivas. Desse modo, nas palavras de Evans: "assim como a tradição de Deméter celebrada em Elêusis permitia aos indivíduos reconstruírem sua concepção do divino e sua relação com as estruturas humanas sociais e políticas inerentes à polis, também Platão no discurso de Diotima apresenta uma concepção diferente da experiência humana e sua distância relativa e diferença em relação ao divino." ${ }^{11}$ Considerando a presença atmosférica de uma temática de iniciação, mas que ainda, como já discutimos, apresenta elementos tradicionais da ritualística ateniense, podemos ver Sócrates, então, como a culminação de toda uma imagética de iniciação.

Loredo encontra ainda muitos outros elementos que demonstram esse parentesco entre a estrutura do Banquete e dos Mistérios de Elêusis, bem como de outros ritos como os de Orfeu e Dioniso, mas não os glosarei aqui, pelo bem da brevidade. Acredito, porém, que os elementos supracitados bastem pelo menos para notar que parece sim haver algum tipo de parentesco entre o Banquete e os cultos de Mistério.

Contudo, se, como somos levados a crer, essa relação de analogia estrutural entre $O$ Banquete e os Mistérios de Elêusis de fato existe, então, há algo de muito estranho na presença de personagens

\footnotetext{
${ }^{11}$ EVANS. Idem., p. 7.
} 
históricos no diálogo que haviam se envolvido em escândalos públicos e acusados de profanação desses mistérios, com a destruição de estátuas de Hermes: Alcebíades, sendo o mais notável, mas Eríximaco e Pausânias também, além mesmo do próprio Sócrates, que por mais que não tivesse se envolvido na destruição das estátuas propriamente ditas, havia sido acusado de algo muito pior, que era, segundo a seção X da Apologia de Sócrates, de negar os deuses que a cidade reconhecia como deuses e de corromper os jovens - uma profanação intelectual, portanto, em vez de material. Qual seria o significado de organizar uma cerimônia análoga à de um culto de mistério com profanadores desse culto?

Para ilustrar a questão, poderíamos dizer que, estabelecendo um paralelo moderno cristão, é como se alguém organizasse uma ceia com ateus ilustres como José Saramago, Samuel Beckett, Richard Dawkins e Carl Sagan (obviamente, ambientada mais ou menos pelos anos 80, quando todos estavam vivos), seguindo uma estrutura semelhante a de uma missa católica - a comparação é ainda mais apta pelo fato de envolver convidados de áreas distintas do conhecimento e da cultura humana. O efeito que se tem é, nitidamente, o de uma profanação de um ritual a princípio sagrado, e o formato de missa, dependendo de como é realizado, se torna uma paródia. E isso constitui uma maneira eficiente de ridicularizar, satirizar, inferiorizar um costume, uma crença, um sistema filosófico, possivelmente em prol de outro. É, por exemplo, o que James Joyce faz em Ulisses, quando o personagem de Buck Mulligan, ao longo de todo o primeiro capítulo do romance, imita atos da liturgia cristã, entoando 
cânticos enquanto se barbeia e fazendo o sinal da cruz para o mar. O que Platão faz, entretanto, não é exacerbar esses elementos de mistério, pois, como mostramos, toda a estrutura subjacente é mais sugerida do que revelada propriamente - se bem que um leitor da época, familiar com a cultura religiosa grega, provavelmente seria capaz de perceber esse parentesco com maior facilidade. $\mathrm{O}$ resultado não é uma paródia caricaturalmente agressiva e flagrante, mas não é de todo inofensiva. Gostaria de me ater um pouco a esse assunto.

Como vimos, Sócrates rejeitava a cultura religiosa típica grega, por motivos mais políticos do que teológicos propriamente, uma vez que o pensamento religioso ateniense havia se tornado, nas mãos do Estado, opressor e inimigo do pensamento livre. $\mathrm{E}$ isso se relaciona intimamente com as ideias apresentadas no Banquete em seu discurso: nele, várias noções distintas são relacionadas e aproximadas - bondade, beleza, virtude, verdade, sabedoria. Podemos vê-las como sendo todas faces diferentes de um mesmo bem e, particularmente, um bem que somente os deuses possuem. Nisso, Ágathon concorda com ele na discussão preliminar anterior à repetição do discurso de Diotima (entre $\$ 200$ a e $\$ 201$ e). Sendo assim, Eros seria um dêmone por não ser nem bom nem belo (portanto não sendo um deus) e tampouco mal e feio, constituindo uma entidade intermediária que busca o belo. Eros se assemelharia então à figura do filósofo, que é quem busca a sabedoria sem jamais conseguir atingi-la - visto que ela é propriedade dos deuses - mas sem ser ele mesmo um ignorante, visto que o ignorante se contenta com sua falta de sabedoria. A questão que se põe, desse modo, é que, se os deuses 
são bons, por que, na representação mitológica-religiosa, eles são antropomorfizados, não só em aspecto físico, mas em emoções e comportamento?

Como se sabe, os deuses clássicos gregos são tão suscetíveis quanto os humanos aos abalos das paixões e sentimentos, como fúria, inveja, luxúria, ciúme, vaidade, etc. Os exemplos da mitologia são numerosos demais para se listar e vão desde as conhecidas escapadas sexuais de Zeus com outras deusas e mortais (muito para a amargura de sua esposa ciumenta), que geraram muitos heróis, incluindo Héracles (ele também muito distante de qualquer ideal de moral), até a vaidade das três maiores deusas demonstrada no Julgamento de Páris. Segundo a concepção de Sócrates, como poderiam, então, os deuses serem sábios e bons, se fossem tão dominados por suas paixões quanto os humanos? A resposta de Sócrates é, pois, negar os deuses, tal como representados tradicionalmente. Nisso, e por mais que ele não chegue a falar explicitamente em monoteísmo, sua concepção se aproxima, de certo modo, a do Deus cristão (mais especificamente do Novo Testamento) que seria eterno, justo, sábio, verdadeiro e perfeito em juízo, além da mais bela de todas as visões (pensemos no final da Divina Comédia em que a Dante é enfim permitido vislumbrar Deus). Obviamente tal concepção representava uma blasfêmia para a sociedade grega da época e isso pesou contra Sócrates na hora de sua condenação. Aristófanes, brilhantemente, parodia a posição socrática em relação com a divindade em sua peça As Nuvens, em que um Sócrates muito arrogante ridiculariza o caipira Estrepsíades por ainda crer nos deuses e o rotula de 
antiquado, afirmando que a força centrípeta é quem domina o universo - um pensamento muito mais próximo, na verdade, do pensamento científico de postura dawkinsiana.

Se os mistérios de Elêusis, então, seguiam ainda uma noção tradicional de divindade, aceitando a representação clássica de Deméter, Prosérpina e Hades (tanto o deus quanto sua morada, onde os iniciados seriam supostamente favorecidos) é de se esperar que Sócrates, tal como caracterizado por Platão - bem como o próprio Platão, se compartilhava das ideias de Sócrates - rejeitasse também os mistérios. Mas há outras questões ainda que nos levam a essa conclusão. Participavam dos Mistérios verdadeiras turbas de pessoas, uma vez que eram populares entre todas as camadas da sociedade, os ritos ocorriam uma vez ao ano e frequentemente um mesmo iniciado participava mais de uma vez. Tal tipo de reunião maciça de pessoas é, como se sabe, inimiga do pensamento filosófico, da reflexão e da contemplação - e sem reflexão e contemplação não é possível se aproximar da verdade. Isso é discutido ainda no Banquete em $\$ 194 \mathrm{c}$, quando Sócrates pergunta a Ágathon sobre a diferença entre a companhia das pessoas envolvidas no banquete e a da plateia que assistiu a sua última peça e ele responde que "um pequeno número de pessoas inteligentes assusta muito mais que uma grande multidão de ignorantes". O fato de que os ritos de Mistério prometiam vida após a morte são um agravante, pois é de se imaginar que essa promessa fosse um grande atrativo para a vinda de muitos iniciados. Contudo, tendo acesso a outros diálogos, como a Apologia de Sócrates e Fédon, vemos a ideia da filosofia como preparação para a 
morte. Na Apologia, Sócrates afirma que temer a morte é uma grande ignorância, pois ninguém sabe, de fato, se ela é boa ou má, e ter a certeza de que é o maior dos males é fingir ter sabedoria, sem tê-la, acreditar saber aquilo que não sabe. Justamente por isso, por não saber o "bastante das coisas do Hades", é que Sócrates se recusa a fugir delas. ${ }^{12}$

Essa ideia ainda é glosada no trecho intitulado "A morte como libertação do pensamento" (na tradução de Jorge Paleikat e João Cruz Costa) de Fédon, em que, com base na dicotomia de corpo e alma, defende-se uma ideia positiva da morte. Com essas noções em mente, torna-se difícil defender um Sócrates que fosse a favor da mistificação da morte promovida pelos mistérios. É de se esperar que os iniciados em Elêusis temessem a morte, tal como representada tradicionalmente pela mitologia e cultura religiosa atenienses: um submundo de sombras, escuro, negativo e esquecido. Assim, aceitando sem questionar essa representação como verdade e como um mal, mesmo não havendo o que prove essa "verdade", o iniciado acaba por temer a morte e busca, na iniciação aos Mistérios, uma fuga desse destino, por mais que não possa saber se a representação que ele aceita seja realmente verdadeira. É não só crer possuir uma sabedoria que não se tem, como também é agir com base nesse falso saber. E, de modo algum, podemos imaginar que Sócrates fosse um defensor da ação ignorante.

\footnotetext{
${ }^{12}$ PLATÃO. Apologia de Sócrates. Tradução de Maria Lacerda de Moura. Rio de Janeiro: Ediouro, 1993, p. 66.
} 
Fica evidente, assim, uma distinção entre os ritos do Mistério de Elêusis, em que há multidões e mistificação, e o Banquete, em que há uma elite pequena e seleta de cidadãos atenienses e que culmina com uma grande revelação e a busca pela verdade surgindo à tona.

Contudo, por mais que Sócrates e Platão se revelem hostis à religião centrada na mitologia tradicional, Sócrates/Diotima ainda fazem uso dos mitos ao explicar a origem de Eros, como filho do Engenho e da Necessidade. E não só Sócrates: todos os comensais fazem menções à mitologia em seus discursos. Contudo, nem todos os comensais devem ser levados a sério. É disso que tratarei agora mais atentamente.

\section{Os Discursos}

Podemos dizer que a maioria dos convivas do Banquete apresenta alguma falha em seu discurso que indica, de algum modo, que ele não deve ser levado totalmente a sério. Começando por Fedro, encontram-se em seu discurso alguns pontos que revelam sua própria inexperiência e as deficiências de uma educação sofista. Primeiramente, ele, como muitos outros, molda o amor à sua própria imagem: o amor de Fedro é um amor que claramente favorece o amado $^{13}$, em vez do amante - e mais especificamente o amado numa relação homossexual - e isso é perfeitamente condizente com o fato de que Fedro representa o papel do amado passivo e imberbe em seu

${ }^{13}$ CORRIGAN. Plato's Dialectic at Play: argument, structure, and myth in the Symposium. Pennsylvania: The Pennsylvania State University Press, 2004. pp. 534. 
relacionamento com Erixímaco. O outro grande problema é que Fedro, como um mitólogo estudante de retórica, manipula e até mesmo distorce o mito para fazê-lo servir à sua tese. Ele apresenta Orfeu como um covarde vergonhoso - uma interpretação muito pouco ortodoxa - e para usar como modelo o forte exemplo de Aquiles, ele o retrata, em sua relação com Pátroclo, como amado, em vez de amante. Creio ser provável que Platão tenha empregado aqui justamente esses mitos por serem dos mais famosos e, assim, tornar mais prontamente reconhecíveis para o público grego as falhas do discurso de Fedro, como que para apontar que os discursos no Banquete não devem ser tomados como doutrina e sim como ponto para discussão, debate e reflexão. Como identifica Corrigan ${ }^{14}$, Fedro é incapaz de ver além de seus próprios desejos e de reconhecer as ideias de Sócrates, mas muitos pontos que Sócrates discute são em resposta aos argumentos de Fedro e pode-se reconhecer seu entusiasmo sincero em relação ao amor como o estopim que inicia toda a discussão. Então, por mais falho que ele se mostre, ele não é um completo ignorante e representa o começo do processo de busca pela sabedoria.

Pausânias também emprega o mito, mas apenas para iniciar a distinção entre corpo e alma, que define todo o tom do discurso; e Corrigan o identifica como um sociólogo ${ }^{15}$, visto que a questão da lei e do comportamento socialmente aceitável entram em discussão em

\footnotetext{
${ }^{14}$ CORRIGAN. Ibid., p. 56.

${ }^{15}$ CORRIGAN. Idem., pp. 56-57.
} 
seu discurso. A princípio, essa distinção entre corpo e alma pode ser reconhecida como platônica e em sua totalidade, a fala de Pausânias é mais capciosa do que a Fedro, exigindo um olhar mais minucioso para expor suas falhas. A mais óbvia, contudo, repousa na sua distinção inicial - difícil para leitores modernos captarem, mas que deveria também ser óbvia para leitores da época - entre uma Afrodite e um Eros Pandêmios e uma Afrodite e um Eros Urânios. Para leitores modernos, a noção de uma beleza e um amor celestiais parece, de fato, ser mais favorável que um amor e beleza vulgares, de todo o povo, porém, como aponta Corrigan ${ }^{16}$, "essa distinção não é apoiada pelo nosso conhecimento das verdadeiras práticas contemporâneas" e que "o título Urânia era a marca da deusa oriental e associada com culto de prostituição". Isso é, como o mal-uso dos mitos de Orfeu e Aquiles em Fedro, uma marca alertando o leitor que ele deve manter alguma desconfiança durante a leitura. E um olhar mais profundo revela que essa marca não é um falso aviso. Há grandes contradições no discurso de Pausânias: primeiramente, sua distinção despreza o corpo, mas não renega a gratificação sexual, tampouco preza o ascetismo - como o neoplatônico Plotino prezaria mais tarde ao manter uma distinção semelhante entre corpo e espírito ${ }^{17}$. Gostaria de estabelecer, de maneira anedótica, um paralelo literário moderno para ilustrar a perniciosidade essa ideia: o escritor

\footnotetext{
${ }^{16}$ CORRIGAN. Idem., p. 62.

${ }^{17}$ PLOTINUS. An Essay on the Beautiful. Translated by Thomas Taylor. 1917. Disponível online pelo Project Gutenberg <http://www.gutenberg.org/etext/29510> Acessado em 20/08/2010.
} 
pós-modernista norte-americano Thomas Pynchon, em seu primeiro

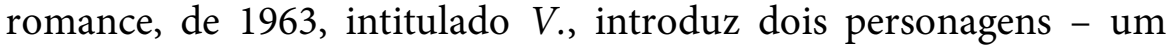
cirurgião plástico e uma cliente - tendo um relacionamento amoroso; e a justificativa do cirurgião para continuar a fazer plásticas na moça, mesmo depois de ela própria estar enfim satisfeita com seu corpo, é a filosofia de que "eu te amo pela sua alma, então posso fazer o que quiser com seu corpo"18 - o que é uma forma comicamente absurda de demonstrar o próprio absurdo de um tipo de pensamento como o de Pausânias.

Em segundo lugar, há trechos que apontam simultaneamente para uma noção do tipo "os fins justificam os meios" - no que diz respeito à classificação de quando um ato é belo ou não - quanto para "os meios justificam os fins" para as leis do amor. Contudo, o convívio de ambas as ideias leva à desregulação da lei, de modo que o é puramente egoísta passa a ser bom - e Pausânias, sem se dar conta, passa a fornecer uma base ideológica para apoiar o comportamento completamente imoral disfarçado de mais alta virtude ${ }^{19}$. Pode-se dizer que seu discurso é ainda pior que o Fedro, pois se Fedro apresentava ainda alguma virtude que o redimia parcialmente, a virtude do discurso de Pausânias é a sua habilidade de falar bem e esconder os pontos fracos de seu argumento para o olhar menos atento, o que aponta para a figura do sofista.

\footnotetext{
${ }^{18}$ PYNCHON, Thomas. V. Suffolk: Picador, 1975, pp. 296-297.

${ }^{19}$ CORRIGAN. Ibid., pp. 61-62.
} 
O próximo seria Aristófanes, mas por ser acometido de uma crise de soluços, Erixímaco toma seu lugar e, tendo um nome que já indica, comicamente, sua profissão ("aquele que combate o soluço"), oferece-lhe conselhos sobre como curá-los e, em seguida, trata de fazer o seu próprio discurso sobre o amor. Nele, ele compõe um longo elogio à ordem na alma, no corpo e na própria natureza, relacionando-a ao bom amor (urânio), ao correto, ao feliz, ao saudável. Aqui, o grande indicador de que há algo de errado em seu discurso repousa na situação em geral: toda a fala sobre a ordem é ironicamente perturbada pela desordem introduzida por Aristófanes com seus soluços, que, inclusive, havia mudado até mesmo a ordem em que os discursos seriam realizados. Ele mesmo comenta como precisou provocar um espirro (também um elemento de desordem) para tratar do soluço e, assim, restabelecer a ordem em seu corpo. Há, sim, aspectos interessantes introduzidos aqui, como a expansão da área de atuação do amor $^{20}$, que Sócrates também desenvolve. Porém, o tratamento que Erixímaco lhes dá é tão obsessivamente ligado à ordem e ao equilíbrio que acaba por excluir uma boa parte da existência humana ${ }^{21}$. Ele, como sendo, de certo modo, um cientista, não faz grande uso do mito, mas trabalha sobre a distinção a princípio mítica entre Afrodite Urânia (o "bom amor", ordeiro) e Pandêmia (o "mau amor", caótico) feita por Pausânias.

\footnotetext{
${ }^{20}$ CORRIGAN. Idem., p. 66.

${ }^{21}$ CORRIGAN. Idem., p. 65.
} 
Evito falar agora de Aristófanes; para ele darei, logo a seguir, um tratamento mais profundo, analisando o seu tratamento do mito, que é algo complexo. Sua complexidade se reflete mesmo no comentário de Kevin Corrigan, que dedica quase 20 páginas apenas para analisar o seu discurso (contraste com as 6 que ele dedica a Fedro), reconhecendo-o como representante de toda uma classe de poetas mitopeicos ${ }^{22}$. Falarei agora do último conviva antes de Sócrates (que também não discutirei aqui), Ágathon.

Corrigan considera o discurso de Ágathon, tendo vindo depois do de Aristófanes, um fracasso, visto que era de se esperar que ele, sendo um poeta trágico, servisse sua musa como Aristófanes serviu a dele ${ }^{23}$. O que temos, contudo, é um discurso altamente retórico, tomado pelo pensamento sofístico. Seus dons de poeta são aplicados na linguagem, que é sonora e repleta de recursos formais (aqui reproduzidos com um bom grau de sucesso pelo tradutor Donaldo Schüler), mas as ideias que ela apresenta são problemáticas. Primeiramente, ele é semelhante a Fedro no seu uso da mitologia como apoio para os argumentos, com a diferença de que, em vez de forçar uma leitura pouco ortodoxa sobre mitos conhecidos, como faz o primeiro discursante, Ágathon declaradamente rejeita a representação que poetas célebres como Hesíodo e Homero fizeram do amor, por mais que elogie o tratamento poético que eles lhes deram. E, no lugar dessa representação, ele sugere uma representação

\footnotetext{
${ }^{22}$ CORRIGAN. Ibid., p. 72.

${ }^{23}$ CORRIGAN. Idem., pp. 85-86.
} 
própria. Em segundo lugar, ele parece levar as, já por si só problemáticas, ideias polarizantes de Erixímaco a um extremo. E, por último, ele, mesmo mais do que os outros, representa o amor como sendo igual a si mesmo. Corrigan identifica nele uma espécie de destilação dos outros discursos, demonstrando seus aspectos fortes mas não os fracos ${ }^{24}$ - o que explica o fato de ele não dar tão claramente, a princípio, nenhum indício de que seu discurso apresenta falhas filosóficas. Assim, se os outros discursos são glorificações de um amor criado à imagem do discursante, o amor que ele representa é jovem (não só jovem, como o mais jovem dos deuses), belo, delicadíssimo e poeta - precisamente como ele mesmo. Mais tarde, é exatamente essa postura que Sócrates critica ao afirmar que todos buscaram fazer o discurso mais (enganosamente) belo, em vez de verdadeiro - que seria o que portaria a real beleza. Corrigan também vê em Ágathon uma figura da abundância ("plenty") em vez da necessidade ("need") como é Aristófanes - e seu discurso reflete isso. O curioso é como a associação de Aristófanes à necessidade o aproxima do próprio amor que Sócrates e Diotima retratam, filho da necessidade e do engenho, também ele uma figura próxima do filósofo. Curiosamente, também, Aristófanes parece não fazer parte do elenco de comensais de discursos egocêntricos, o que o aproxima de Sócrates. Isso também requer alguma atenção.

${ }^{24}$ CORRIGAN. Idem., p. 92. 


\section{Mito e Mímese em Aristófanes}

A presença de Aristófanes aqui é uma presença curiosa. Por mais que ele e Ágathon sejam ambos poetas dramáticos, tudo indica que parece que é a Aristófanes que cabe o papel de representante do autor de literatura no Banquete. $\mathrm{O}$ discurso que ele profere sobre o amor não é tanto um discurso como o dos outros em que se apresenta a defesa de uma ideia quanto é uma narrativa, com um pequeno comentário (uma "moral", por assim dizer) no final, cuja presença pode muito bem ser por motivos cômicos (discutirei isso adiante). Mais especificamente, essa narrativa é de natureza mitopeica, no sentido não de que explora mitos anteriores, comuns já a mitologia compartilhada pela cultura grega, como fazem os outros convivas, mas que, sim, cria um mito novo. Desse modo, para analisar o discurso de Aristófanes, recorrerei a Harold Bloom e o método que ele apresenta em Shelley's Mythmaking ${ }^{25}$, ao empregar uma noção de mito desenvolvida pelo teólogo judeu Martin Buber para analisar uma porção da poesia do poeta inglês do século XIX Percy Bysshe Shelley. Pode parecer estranho, a princípio, tomar como base as ideias de crítico literário que analisa um poeta tão temporalmente distante de Platão, mas não podemos deixar de ver em Shelley um descendente romântico de um tipo de poesia que, como Corrigan ${ }^{26}$ identifica, é representado por Aristófanes. Além do

\footnotetext{
${ }^{25}$ BLOOM, Harold. Shelley's Mythmaking. New Haven: Yale University Press, 1959.

${ }^{26}$ CORRIGAN. Ibid.., p. 72.
} 
que, me parece ser mais do que uma mera curiosidade o fato de que Shelley não só escreveu e traduziu poesia, como ainda traduziu mais especificamente o Banquete de Platão.

Para se fazer a análise que proponho, claro, faz-se necessária aqui uma breve explicação acerca desse método.

Para Buber e Bloom $^{27}$, há dois tipos de relações que uma consciência, um Eu ("I") pode estabelecer com o mundo: uma relação de Coisas ("It") e de Tus ("Thou"). Segundo o estudo dos irmãos Frankfort $^{28}$, a experiência do homem primitivo é essencialmente composta por Tus - e o mundo, para eles, é algo vivo, com o qual se relacionam intimamente, em vez de meramente experienciar, como o faz o homem moderno cercado por Coisas. E é partir dessa relação íntima que reconhece em outro ser uma consciência parecida com a do próprio $\mathrm{Eu}$ que se cria o mito, elemento constituinte para essa sociedade primitiva ao mesmo tempo de uma forma de se ver e explicar o mundo, de um sistema moral e de religião, fundamentando toda a cultura posterior mesmo depois da derrota do sistema do mito. Segundo esse ponto de vista, a sociedade primitiva não é animista nem personifica o mundo, preenchendo um mundo vazio de fantasmas, mas sim, vive com ele reconhecendo-o como vivo. É essa situação que Buber e Bloom chamam de evento relacional ("relational event"), que se dá entre um Eu e um Tu e que, infelizmente, está fadado a se encerrar; e o Tu se torna uma Coisa. Da

\footnotetext{
${ }^{27}$ BLOOM, Harold. Ibid., pp. 1-5.

${ }^{28}$ apud BLOOM. Idem., p. 5.
} 
mesma forma, uma Coisa, como as que preenchem o mundo do homem moderno, pós-estágio-primitivista, também pode, ao passar pelo evento relacional, se tornar um Tu e então retornar a ser uma Coisa quando ele se encerrar. Na crença judaica, Iavé representa eternamente em evento relacional com seu povo escolhido, sendo simultaneamente um Eu para o Tu que são os judeus e um $\mathrm{Tu}$, se considerarmos os judeus como Eu. Segundo Bloom, é o Tu que não pode jamais se tornar uma Coisa, constituindo o grande Mito a construir a religião judaica e rejeitar todos os outros mitos ${ }^{29}$. A ciência, cria da filosofia, também se torna hostil ao mito, ao passo que a própria filosofia começa a rejeitá-lo. É sobre esses pilares que a poesia mitopeica se constrói e a narrativa contada por Aristófanes parece se encaixar perfeitamente nesse modelo, por mais que Platão não a tenha escrito em verso.

O mito que ele conta é o de como cada homem e mulher, que a princípio formavam um só ser, passaram, ao cometer o pecado da hybris, a serem criaturas separadas, ansiando eternamente o retorno a essa união primordial - e esse anseio seria o Amor. Aplicando as noções de Buber, glosadas por Bloom, podemos identificar nesse ser primordial duplo, que pode ser dois homens, duas mulheres ou um andrógino (homem e mulher), dois Eus distintos, eternamente na posição de Eu e Tu um para o outro. Assim, cada ser porque vive um evento relacional infinito é um ser completo, por mais que vivam como animais. Contudo, se a relação do Eu com Deus ou os deuses é

${ }^{29}$ BLOOM. Idem, p. 4. 
ou deve ser também um evento relacional infinito, a completude de cada indivíduo passa a representar um problema. Se deveria haver uma necessidade de um evento relacional infinito, e ele já é suprido do berço, ele deixa de ser uma necessidade e cada indivíduo não mais precisa estabelecer um evento relacional com os deuses. Isso parece ser um motivo muito mais razoável para explicar a hybris cometida pelos homens primordiais do que a suposta força e velocidade que suas formas esféricas possuiriam, que lhes permitiria desafiar os deuses. A decisão de Zeus de partir os homens em dois resolve o problema, pois faz de cada ser dois Eus distintos, que passam a viver, em relação com os outros seres, uma relação de Coisa, e nessa situação, apenas um outro ser específico - a outra metade - pode vir a representar um $\mathrm{Tu}$. Mas esse evento relacional que pode ocorrer agora entre as duas metades partidas não é mais perfeita e duradoura como a anterior. Como todo evento relacional mítico, ele tem um fim, quando o $\mathrm{Tu}$ se torna uma Coisa e a incompletude retorna. Se essa relação é o amor, então o que Zeus fez foi transformar o amor infinito anterior num amor finito, que cessa ou por causa da vivência que leva o casal à frieza emocional ou por mais que esse amor dure toda a vida, eventualmente uma das partes há de morrer e então, forçosamente, tornar-se uma Coisa - o que não ocorreria quando os dois seres eram um só, que, presumivelmente, morrendo, morreriam os dois. Como já não há mais como se estabelecer um evento relacional eterno com outros mortais, os homens passam a precisar dos deuses para estabelecer essa relação e se completarem. Dessa forma, a decisão de Zeus é ao mesmo tempo um castigo e uma 
solução e o comentário jocoso de Aristófanes, sobre precisarmos louvar os deuses por medo de sermos partidos ao meio de novo, faz todo sentido.

Tal é minha leitura mitopeica do discurso de Aristófanes que, como podemos ver, não cria o amor à sua imagem e semelhança como os outros convivas do Banquete. Aristófanes é um poeta, um comediante, um satirista, um artista, mas ainda assim não cria a imagem de um amor artista ou mesmo cômico por si mesmo, por mais que o modo de apresentação dele seja ele mesmo repleto de piadas. Também os elogios à sua beleza são contidos. Ágathon também é poeta, mas talvez por ser mais inexperiente, não parece ter sido aqui o eleito para ser o representante da literatura, como Aristófanes o é; e ele comete o erro filosófico de criar o amor à sua própria semelhança. Aristófanes, como poeta maduro, não faz da literatura veículo para forçar sua própria imagem sobre o mundo e nisso se assemelha ao filósofo, no sentido de que a literatura é, de certa forma, uma fuga de si mesmo também. A criação de personagens dramáticos ou épicos ou mesmo de uma persona para poesia lírica significa ter de sair de si mesmo e imaginar e prever comportamentos alheios, para tirar da relação entre essas criações ficcionais, uma Verdade que valha para o mundo real. O próprio público de um espetáculo teatral também deve abdicar de si mesmo na hora de assistir a uma peça ou ouvir a declamação de um poema, pois tem de dar ouvidos à voz de outra pessoa sobre outras pessoas que podem sequer existir. Desse modo, o discurso de Aristófanes se distancia de todos os outros, senão o de Sócrates. 
Entretanto, além da parte narrativa do discurso aristofânico, há ainda uma parte discursiva propriamente dita em que ele expõe sua própria leitura sobre o mito que acaba de contar. Ele diz que os homens descendentes dos homens duplos primordiais são guerreiros viris, as mulheres descendentes das mulheres duplas primordiais são muito femininas e os homens e mulheres descendentes dos andróginos são perpetuadores de adultérios. Essa é uma afirmação que não podemos tomar prontamente sem alguma reflexão. A impressão que se tem com essa afirmação é a de que Aristófanes era um defensor fervoroso da homossexualidade. Mas um contraste com o Aristófanes verdadeiro, pessoa empírica e não personagem de Platão, revela algumas nuances que complicam essa leitura. Por exemplo, um sério obstáculo para a hipótese de que Aristófanes seria a favor da homossexualidade são as piadas constantes que o autor faz sobre homossexuais em suas comédias como As Nuvens e as Tesmoforiantes, que de maneira hilariante, apresentam Ágathon como alguém afeminado (tamanha sua delicadeza) e onde Mnesíloco exclama, ao ser barbeado para se travestir, que ele está parecendo Cleistenes, um homossexual aparentemente famoso na Grécia da época e alvo constante das piadas de Aristófanes. A ideia também de que a heterossexualidade seria algo ruim e deturpadora de valores, $\mathrm{e}$ que as mulheres corretas tenderiam a gostarem mais de outras mulheres, se revela difícil de se aplicar a Lisístrata, onde, muito comicamente, um dos primeiros obstáculos à revolução feminina causada pela greve de sexo é justamente o amor que as personagens têm ao sexo com homens. Torna-se assim difícil de aplicar as noções 
do personagem platônico Aristófanes ao verdadeiro Aristófanes, o que complica ainda mais qualquer tentativa de compreender as intenções de Platão com isso. Muito possivelmente pode ser que ele estivesse fazendo piada com Aristófanes, o que não seria de todo estranho. O Banquete é uma obra largamente seriocômica, como reconhece Bakhtin ${ }^{30}$, e Platão presta uma atenção especial às piadas com o personagem de Aristófanes, justamente por ele ser um poeta cômico. O comentário enigmático sobre autores de tragédia serem capazes de comporem comédias também, feito no final, também poderia ser vislumbrado sob esse ponto de vista irônico-cômico, uma vez que, como vimos, o discurso de Ágathon, o poeta trágico aqui, é inferior ao do poeta cômico.

Contudo, o discurso de Aristófanes apresenta uma falha se visto sob uma ótica que sistematize a filosofia de Platão: ele pretende ensinar algo (p. 71 - rivalizando, portanto com a filosofia), ao mesmo tempo que incorpora basicamente todos os problemas da poesia mimética que a República critica e que restringem a arte (pp. 70-3) e a busca do Eros de Aristófanes pela completude visa a restauração de um estado de ignorância animalesca que era a do homem primordial (p. 74), em vez de ser a busca pela sabedoria. Ele é ao mesmo tempo poderoso, contraditório, mais verdadeiro que os outros discursos (por mais que ficcional) e, em muitos sentidos, antagônico em relação à filosofia e é até mesmo um veículo para Platão parodiar seu próprio método dialético (p. 82).

\footnotetext{
${ }^{30}$ BAKHTIN, Mikhail. Problems of Dostoevsky's Poetics. Minnesota: University of Minnesota Press, 1984, p. 109.
} 


\section{Uma Possibilidade de Reconciliação}

Novamente, retorno a Bloom e sua leitura do mito. Por mais que ele trate mais especificamente do mito numa porção delimitada da poesia de um autor muito distante temporalmente de Platão, ela é uma leitura que se aplica aqui também. Ele diz: "O aspecto final da mitopeia de Shelley é que o mito e o criador do mito, estão plenamente conscientes da derrota necessária do mito. Não há Tus para o relacionamento no Triunfo da Vida [poema de que trata Bloom nesse capítulo]; o poema comemora o triunfo da Coisa da experiência." ${ }^{31}$ Como todo mito tende a um fim, do qual o poeta mitopeico está consciente, com a redução do mundo a um mundo de Coisas, torna-se difícil manter a crítica da arte mimética quando a própria arte está consciente da derrota de sua substância. De qualquer modo, há algumas semelhanças entre o poeta e o filósofo, demonstradas por Platão: ambos são figuras de intermédio - visto que a musa é quem fala através do poeta; tanto Aristófanes quando Sócrates recorrem ao mito; ambos estão ligados à figura da Necessidade; ambos representam uma fuga do eu; e ambos mais que a retórica e a ciência dão conta de exprimir a totalidade da experiência humana. Retomando Bakhtin ainda, tanto a forma do diálogo platônico quanto a da comédia são formas literárias próximas por serem seriocômicas e carnavalizantes ${ }^{32}$. Assim, nota-se que talvez a grande diferença entre as duas atividades - a arte literária e a

\footnotetext{
${ }^{31}$ BLOOM. Ibid., pp. 274-275.

${ }^{32}$ BAKHTIN. Ibid., p. 129.
} 
filosofia - repousam mais numa questão de postura do que qualquer outra coisa: Aristófanes é cínico (no sentido moderno da palavra) e a sua obra literária é independente de seus próprios pensamentos, ao passo que Sócrates mantém suas posições mesmo quando condenado à morte. A literatura tem seus limites, mas a filosofia também, uma vez que os ensinamentos de Sócrates, o grande fundador da filosofia, se perderiam por ele ter sido condenado à morte e por aceitá-la tão prontamente, sem nunca ter escrito nada. Sabemos o quanto a literatura, por ser erotizada, aspira a imortalidade através da beleza. $\mathrm{E}$ como o bom e o belo são interligados, Platão pode ter visto nela uma maneira de perpetuar a filosofia. E, assim, nasce o Banquete.

Como podemos notar, minha argumentação seguiu um caminho de, primeiramente expor e comentar as semelhanças entre a estrutura do Banquete e os ritos de iniciação dos Mistérios de Elêusis, bem como apontar para as diferenças que permitem encontrar nessa estrutura uma paródia sugestiva de uma certa superioridade da filosofia sobre a superstição mitológica, com possível base nas diferentes possibilidades de uso do mito. A filosofia é uma preparação para aceitar a morte, em oposição a negá-la desejando benefícios póstumos; é a contemplação e transmissão de conhecimento entre poucos em lugar de estupefação em grandes multidões; é pensar sobre os mitos em vez de aceitá-los como uma verdade imposta pela sociedade e pelo governo. A seguir, analisamos individualmente os discursos dos convivas do Banquete com o intuito de demonstrar um certo favorecimento do discurso de Aristófanes por parte do autor ao compará-lo em alguns pontos com 
o discurso de Sócrates, já reconhecido há tempos como superior em verdade aos outros discursos.

Com essa discussão espero ter defendido que, por mais que, como se sabe, Sócrates/Platão tenham expulsado os poetas na República, Platão reconhece, pelo menos em algum grau, a literatura como irmã e semelhante da filosofia em sua busca pela melhoria do homem, por mais que a postura das diferentes disciplinas revelem por vezes um certo antagonismo. E o resultado disso é o próprio Banquete, além do restante das produções dialéticas de Platão: sua forma, mesclando o discurso filosófico com elementos literários altamente estetizados, cuja interpretação é fundamental para a compreensão das ideias apresentadas, é icônica dessa noção e representa uma aproximação entre as duas atividades, buscando não só a sabedoria ou a imortalidade pela beleza, mas a própria imortalização pelo bem e pelo belo da busca da sabedoria.

\section{Bibliografia}

ARISTOPHANES. The Complete Plays. Translated by Paul Roche. New York: New American Library, 2005.

BAKHTIN, Mikhail. Problems of Dostoevsky's Poetics. Minnesota: University of Minnesota Press, 1984.

BLOOM, Harold. Shelley's Mythmaking. New Haven: Yale University Press, 1959. 
CORRIGAN, Kevin. Plato's Dialectic at Play: argument, structure, and myth in the Symposium. Pennsylvania: The Pennsylvania State University Press, 2004.

GONZÁLEZ, Francisco J. The Third Way: new directions in platonic studies. London: Rowman \& Littlefiled, 1995.

EVANS, Nancy. Diotima and Demeter as Mystagogues in the Symposium. In: Hypatia vol. 21, no. 2. 2006.

LOREDO, Carlos Roberto. Eros e Iniciação: Um estudo sobre as relaçães entre a paidéia platônica e os antigos cultos gregos de Mistério a partir do Banquete. Dissertação de Mestrado. Belo Horizonte: FAJE, 2009.

PLATÃO. Apologia de Sócrates. Coleção Universidade. Rio de Janeiro: Ediouro, ano não informado.

. Diálogos II: Fédon - Sofista - Político. Tradução de Jorge Paleikat e João Cruz Costa. Coleção Universidade de Bolso. Rio de Janeiro: Ediouro, ano não informado.

. O Banquete. Tradução de Donaldo Schüller. São Paulo: L\&PM, 2009.

PLOTINUS. An Essay on the Beautiful. Translated by Thomas Taylor. 1917. Disponível online pelo Project Gutenberg $<$ http://www.gutenberg.org/etext/29510> Acessado em 20/08/2010.

PYNCHON, Thomas. V. Suffolk: Picador, 1975. 